\title{
Partnerships for better nutrition - an analysis of how Danish authorities, researchers, non-governmental organizations and practitioners are networking to promote healthy eating
}

\author{
Bent Egberg Mikkelsen and Ellen Trolle \\ Department of Nutrition, Danish Institute for Food and Veterinary Research, Søborg, Denmark
}

\section{Abstract}

Background: The increase in nutrition-related diseases in industrialized countries is alarming. Unhealthy eating habits, lack of physical activity, excessive alcohol consumption and tobacco are the main causes of this development. There is therefore great interest in prevention strategies. Such strategies have traditionally been based on public information or regulation, but in recent years the value of partnership has begun to be discussed. Design: Evaluation of 13 concrete Danish partnership initiatives for promoting healthy eating habits was carried out using a 10 -step checklist.

Results: The evaluation showed that the partnerships in general were quite successful. Most partnerships were assessed to have resulted in concrete output, to have been disseminated well in target groups, to have had high novelty value and to have brought new resources into play. Major weaknesses in the partnerships were reported to relate to the time-consuming task of setting up partnerships. Results also showed that a number of requirements should be met if partnerships were to be successful.

Conclusions: The study indicates that partnerships are a promising tool in the promotion of healthy eating habits as seen from a public point of view. Partnerships should be seen as a supplement to tools such as information, regulation and state interventions, and therefore businesses and non-governmental organizations are important actors in partnerships. It is suggested that businesses, in particular, should develop their role in future partnerships and that they should aim develop their responsibility for the nutritional effects of the products they sell. The term corporate nutritional responsibility is suggested to describe such effort aimed at making nutritional issues a corporate management issue.

Keywords: corporate nutritional responsibility; healthy eating; networks; partnerships

Received: 17 Dec. 2003; Revised: 2 Mar. 2004; Accepted: 5 Apr. 2004

\section{Introduction}

The increase in nutrition-related diseases in industrialized countries is alarming. Unhealthy eating habits, lack of physical activity, excessive alcohol consumption and tobacco are the main causes of this development. The result can be seen in health statistics. Rates of obesity have risen sharply during the past 30-40 years, as has the risk of sequelae such as type 2 diabetes. The World Health Organization (WHO) has identified the obesity epidemic as one of the biggest health problems in the general population, and worldwide there are now more people who are overweight than underweight (1).
In Denmark, there has been a tripling of overweight and obesity in children and young people in the last 30 years (2). Therefore, there is a need for effective strategies to promote healthier lifestyles and eating habits that follow official recommendations more closely.

The traditional approaches for promoting suitable developments in society are often either regulation or market controls. In recent years an increased focus has developed on a third way: partnerships between the authorities and businesses. In such partnerships the partners can work together in an attempt to promote a desirable development in 
society, such as healthier nutrition. In addition to the authorities and businesses, researchers, practitioners, educational institutions and health-promoting non-governmental organizations (NGOs) are actors that play a role in the formation of partnerships for healthier eating habits.

The phenomenon of partnership has been the focus of public debate for a long time. In international development aid (3) the concept has gained acceptance as a term for describing the fact that development aid can only produce the desired effect if it is granted and implemented by close cooperation among donors, local authorities and local NGOs.

In industrial policy the concept has frequently been used to describe a development by which public sector customers to an increasing extent enter into binding partnerships with the private sector in public-private partnerships $(4,5)$ for the development of the value of various forms of goods and services used by the public sector. This approach has been especially developed in the USA. In Europe there has been a particular focus on the role that social partnerships have played in the regulation of the labour market by trade unions and employers.

In the health sector there are good examples of health promotion in partnership between authorities and local partners (6). These partnerships have developed in particular around certain settings such as schools, workplaces and cities.

In environmental regulation partnership and networks have developed between companies and authorities over the past few decades. Such partnerships have resulted in the development of new, cleaner technologies. Partnerships have also been used to develop regulatory alternatives to traditional legal regulation (7).

In industry there is a long tradition of commercial partnerships between customers and suppliers. Such partnerships have been described in the literature on supply chain management $(8,9)$.

Some of the experiences from different fields of society form the basis of the theoretical considerations of partnerships by Håkansson and Snehota (10). They studied bilateral and multilateral business relationships and developed a conceptual framework for understanding such networks. In this framework networks are envisaged as a bringing together of activities, resources and actors.
The aim of the study was to analyse experiences from ongoing partnership projects promoting healthy eating, and to discuss and point out the perspectives in promoting healthy eating through such partnerships. The objectives were: (1) to identify and characterize existing partnerships in terms of actors, resources and activities; (2) to point out strengths and weaknesses in existing partnerships based on an evaluation of their success; (3) to point out conditions and requirements for the creation of successful future partnerships; and (4) to discuss the perspectives in future partnerships.

\section{Methods}

The paper is based on an analysis of 13 concrete partnership projects concerning the promotion of healthier eating habits presented at a conference on partnerships for healthy food organized by the Danish Ministry of Food, Agriculture and Fisheries on 2 October 2003 in Copenhagen (11). The purpose of the conference was to present concrete examples and discuss how NGOs, businesses, the authorities and researchers could enter into and run partnerships that promote healthy nutrition.

In the call for abstracts on posters about partnerships it was specified that they should be a bilateral or multilateral cooperation between one or more institutional actors, should contain a concrete target of healthier eating and should seek to achieve this through a well-defined activity. The call for abstracts further specified that research projects and purely commercial partnerships were outside the scope of the poster session. The conference was announced via direct letters to a large number of NGOs and businesses, and potential participants were asked to submit abstracts for posters to be reviewed by the conference committee.

Based on the abstracts a number of partnerships was selected and invited to prepare a poster and the oral presentations with a description of the partners, background, purpose and results. The authors of the posters were asked to describe how the collaboration was organized to evaluate it.

The analysis carried out by the authors of this paper was focused on determining the success of existing partnerships, and in this process several of the posters were left out since they did not fully meet the criteria set up in the call. Furthermore, it was decided that the evaluation should take the perspective of the public (authorities or researchers) as a starting point. Only partnerships that included 
at least one authority or research partner were included in the evaluation.

The evaluation was done using Håkansson's notions on resources, activities and actors in networks. Thus, in the context of this paper, resources and activities are seen as items that are controlled by each individual partner and can be brought into play in the partnership.

Success was assessed using a 10-step checklist in which both the positive and negative sides of partnerships could be assessed. The checklist contained questions for both strengths and weaknesses, which should be assessed on a five-point scale. The checklists were filled out by the authors together with a representative from each particular partnership. The 10 questions were as follows.

\section{Strengths}

- Did the partnership result in short-term concrete and measurable output?

- Did the partnership result in long-term effects?

- Has the output been disseminated in target groups?

- Have the partnerships set new agendas (novelty value)?

- Have the partnerships brought new resources into play?

\section{Weaknesses}

- Was it difficult to reach consensus in the partnership?

- Was the partnership time consuming for the public part?

- Were resources balanced between partners?

- Were results too unspecific?

- Could results have been reached without partnership?

Besides filling out the checklists, the representatives were asked for additional comments on strengths and weaknesses in their particular partnership. In addition, the self-assessments of strengths and weaknesses done in some posters were taken into account. Based on the results from the assessment of strengths and weaknesses in partnerships and taking into account the statements in the posters, conditions and requirements for successful future partnerships were pointed out and discussed.

\section{Results}

Bearing in mind that the selection of partnerships may be slightly biased, the partnerships in general were evaluated to have been successful. The bias stems from the fact that partnerships that were considered successful were more likely to submit an abstract than partnerships that were not. Therefore, it is assumed that there is a higher prevalence of better practices of partnerships in the study.

In general, the partnerships resulted in concrete, recognized and measurable outputs, such as a product, new knowledge or campaign material. In most cases the partnership had received good coverage in the media and was disseminated well in the different target groups.

In most cases partnerships were assessed to have high novelty value and to have contributed to setting new agendas for promoting healthy eating. The most mentioned feature of partnerships was the ability of partnerships to bring into play different resources complementary to the resources that the individual partners control. Thus, for public partners it was assessed as having been a positive experience to be able to gain access to some of the financial resources as well as the distribution channels that businesses control.

For the public partners the ability to take advantage of the creativeness of the NGOs, as well as their direct access to important target groups, was assessed as being valuable. An important reason for businesses to participate in partnerships was stated to be the ability to take advantage of the authoritative knowledge and the credibility that characterize public partners. In all partnerships much of the creativeness and variety of solutions brought into play could be credited to the existence of the partnership: no representatives of partnerships believed that the solutions and results could have been obtained without the partnership.

Apart from the 6-a-day partnerships, which resulted in significant long-term effects, it is not possible to assess the long-term effect of the partnerships since many of them are ongoing or have only finished recently.

Significant drawbacks identified in the evaluation were related to the time-consuming process of developing the partnerships. For the public partners it was underlined that they often were forced to invest considerable human resources to balance the financial and other powerful resources that businesses brought along. Some representatives of 
partnerships stressed that for partnerships to be successful, partners should all bring their different resources into the partnership in amounts that should be balanced equally across the partnership.

According to business and organizations, the changing political agenda, which is a characteristic of public partners, was a major problem in partnerships involving public partners. Finally, a general drawback was in some cases reported to relate to the fact that it is difficult to be able to expose all partners equally and that more media-experienced partners tend to obtain a greater share of the publicity.

In general, few problems in reaching consensus were reported. This is probably due to the fact that most of the partnerships had spent considerable time planning the partnership and hence had reached a consensus on major issues before launching the partnership. In the 6-a-day campaign partnership the objective was to coordinate campaign activities conducted by several individual partners and therefore it was necessary to work harder on reaching consensus than in other partnerships with a more concrete objective.

The full range of partnerships is shown in Table 1. The layout of the table is based on a modification of Håkansson's model of analysis in which a partnership is characterized according to its actors, resources and activities. The table includes a characterization of the partnerships according to the type of activities carried out. The typology of activities groups the partnerships' initiatives into four different types, shown in Table 2. In addition, a fifth type is proposed, as mentioned and discussed later.

\section{Activities}

Campaign activity is the most common type of activity in the partnerships and comprises activities with a specific message targeted at a specific group of individuals. Partnerships aiming at creating new knowledge necessary for promoting healthy eating were also represented by a number of cases. The nature of such partnerships is more explorative, with the aim of developing new knowledge.

A third type was partnerships with the objective to promote the use of specific healthy foods. These were represented by different partnerships on the 6-a-day platform. A fourth type aims at developing new healthy products and was only represented in one case. In this case a range of healthy foods for fast food outlets was developed.
A fifth type is "transcendental partnerships", which aim to create a governance of food companies. The term corporate nutritional responsibility (CNR) is suggested for this type, and although they are the most demanding they are very promising, as discussed later.

\section{Actors}

The evaluation shows that three types of actor in particular are important partners in promoting healthy eating: public partners such as authorities or research institutions, businesses and NGOs. These actors are represented in all the partnerships and the evaluation shows that they all have important roles to play. In addition, partners from educational institutions and from the practitioner level were present in some of the partnerships. NGOs participating in the partnerships all represent professional NGOs, i.e. organizations that have a budget allowing employment of professional staff as well as other resources. The NGOs represent two types: trade NGOs and health-promoting NGOs.

A list of the 193 participants at the conference shows that NGOs together with businesses were represented most strongly, followed by the authorities, researchers and representatives from educational institutions. NGOs are very often engaged in the partnerships, as seen in Table 1, and this is similar to the case of partnerships found in international development aid and health promotion.

As pointed out by many partners, the strength of NGOs lies in their easy and direct access to the target group. This is a particular strength in campaign partnerships. NGOs enjoy high credibility and the speed with which decisions are made is often good. There are, however, great differences in the resources that NGOs have at their disposal.

Authorities were involved in many of the partnerships. The authoritative role that is achieved through this was assessed to be a strength. However, weaknesses were also pointed out. In state authorities the decision-making process can be slow and the political ties of public authorities can complicate cooperation because officials seldom have the power to make binding agreements. This was pointed out as a major problem and is particularly true because partnership projects do not involve tried-and-tested or routine activities but, on the contrary, activities that require an experimental approach. Such ap- 
Table I. Overview of the title, types of actor, purpose and activities in recent Danish partnership initiatives

\begin{tabular}{|c|c|c|c|c|}
\hline Title & $\begin{array}{l}\text { Actor } \\
\text { type }\end{array}$ & $\begin{array}{l}\text { Activity } \\
\text { type }\end{array}$ & Purpose & Activities \\
\hline $\begin{array}{l}\text { Fit for flight: healthier food } \\
\text { for aircrew }\end{array}$ & $\mathrm{O}, \mathrm{R}, \mathrm{A}$ & DP & To prepare and implement a food and meal policy & $\begin{array}{l}\text { Consultations with professionals and representatives from } \\
\text { organizations. Exchange of experiences on implementation } \\
\text { of healthier food and meal schemes }\end{array}$ \\
\hline $\begin{array}{l}\text { Care through food and } \\
\text { drink }\end{array}$ & $B, A, R$ & $\mathrm{CP}$ & $\begin{array}{l}\text { To increase home helpers' knowledge of nutrition for the } \\
\text { elderly. To raise home helpers' awareness of the signs of } \\
\text { bad nutrition }\end{array}$ & $\begin{array}{l}\text { Preparation of mini-handbook illustrated with photographs } \\
\text { Running three theme days on the issue }\end{array}$ \\
\hline $\begin{array}{l}\text { Food and movement in } \\
\text { kindergartens }\end{array}$ & $\begin{array}{l}\mathrm{O}, \mathrm{A}, \mathrm{B}, \\
\mathrm{R}\end{array}$ & $\mathrm{CP}$ & $\begin{array}{l}\text { To inspire kindergartens to work in a professional way } \\
\text { with healthy food and exercise as part of their daily } \\
\text { routines }\end{array}$ & $\begin{array}{l}\text { Preparation of a website with advice and inspiration about } \\
\text { healthy food and sports games }\end{array}$ \\
\hline The world kitchen & $B, A, R$ & $\mathrm{DP}, \mathrm{CP}$ & To prepare and implement a dietary policy for the canteen & $\begin{array}{l}\text { Preparation of a dietary policy for Scandinavian Airlines, } \\
\text { Copenhagen, food for its ground-based staff }\end{array}$ \\
\hline $\begin{array}{l}\text { Food and meal policies in } \\
\text { schools }\end{array}$ & $\mathrm{O}, \mathrm{R}, \mathrm{A}$ & DP, CP & To inspire schools to prepare a food and meal policy & $\begin{array}{l}\text { Preparation of the idea catalogue "Food and meal policies } \\
\text { in schools - why and how" }\end{array}$ \\
\hline $\begin{array}{l}\text { Food for children in } \\
\text { day-care centres and } \\
\text { schools }\end{array}$ & $\mathrm{O}, \mathrm{R}, \mathrm{A}$ & DP & $\begin{array}{l}\text { To promote healthy food and meal schemes in Danish } \\
\text { schools and institutions }\end{array}$ & $\begin{array}{l}\text { Carrying out of preliminary study. Preparation of inspira- } \\
\text { tion materials }\end{array}$ \\
\hline 6-a-day at the workplace & $\begin{array}{l}\mathrm{O}, \mathrm{B}, \mathrm{R} \\
\mathrm{A}\end{array}$ & CP, PPP & $\begin{array}{l}\text { To develop and implement a fruit subscription programme } \\
\text { in the workplace paid for by the employers and a } \\
\text { programme for workplace canteens to increase the } \\
\text { amount of fruits and vegetables served during lunch }\end{array}$ & $\begin{array}{l}\text { Implementing pilot projects, measuring effect on intake, } \\
\text { ensuring business and canteen participation, dissemination, } \\
\text { building networks and advocacy }\end{array}$ \\
\hline 6-a-day in retail & $\mathrm{O}, \mathrm{R}, \mathrm{A}$ & DP, PPP & $\begin{array}{l}\text { To test whether sales promotion activities in retail outlets } \\
\text { can increase consumers' consumption of fruit and } \\
\text { vegetables }\end{array}$ & $\begin{array}{l}\text { Evaluating effect of sales demonstrations, marketing, } \\
\text { pricing, visual product quality and taste, as well as staff } \\
\text { training, on sale and consumption }\end{array}$ \\
\hline $\begin{array}{l}\text { Food, hygiene and } \\
\text { microorganisms for } \\
\text { schools }\end{array}$ & $O, A$ & $\mathrm{CP}$ & $\begin{array}{l}\text { To develop teaching materials for school pupils about } \\
\text { good kitchen hygiene and the microbiology of food from } \\
\text { the ground to the table }\end{array}$ & $\begin{array}{l}\text { Publishing and marketing of extensive multidisciplinary } \\
\text { teaching materials for } 0-10 \text { classes for home economics, } \\
\text { nature/technology studies, biology, social studies and } \\
\text { health teaching }\end{array}$ \\
\hline The 6-a-day campaign & $\begin{array}{l}\mathrm{O}, \mathrm{B}, \mathrm{A}, \\
\mathrm{R}\end{array}$ & $\mathrm{CP}$ & $\begin{array}{l}\text { To communicate the health benefits of eating } 600 \mathrm{~g} \text { of fruit } \\
\text { and vegetables per day and practical consumer strategies } \\
\text { for achieving this goal }\end{array}$ & $\begin{array}{l}\text { Coordinating activities, building awareness, ensuring } \\
\text { shared ownership, research on effective strategies for } \\
\text { increasing consumption, increasing availability and readi- } \\
\text { ness-to-eat }\end{array}$ \\
\hline 6-a-day school fruit & $\begin{array}{l}\mathrm{O}, \mathrm{B}, \mathrm{A}, \\
\mathrm{R}\end{array}$ & CP, PPP & $\begin{array}{l}\text { To market the school fruit concept, a parent-paid } \\
\text { subscription scheme for schoolchildren, as part of } \\
\text { improving children's health }\end{array}$ & $\begin{array}{l}\text { Handouts, posters, school visits and events, drawing } \\
\text { competition, computer game, website, evaluation and } \\
\text { advocacy }\end{array}$ \\
\hline $\begin{array}{l}\text { Development of a healthy } \\
\text { fast food product range }\end{array}$ & B & PDP & $\begin{array}{l}\text { To develop a healthy series of products for the fast food } \\
\text { outlets of Danish railways }\end{array}$ & $\begin{array}{l}\text { Study of consumer expectations, product development and } \\
\text { kick-off of marketing initiative }\end{array}$ \\
\hline $\begin{array}{l}\text { Cooperation between } \\
\text { retailers and producers } \\
\text { on healthy food }\end{array}$ & $\begin{array}{l}\mathrm{A}, \mathrm{O}, \mathrm{B} \\
\mathrm{R}\end{array}$ & $\mathrm{CP}$ & To make it easier for the consumer to choose healthily & $\begin{array}{l}\text { Marketing a leaflet through a chain of shops developed into } \\
\text { a cooperation with many chains in which distribution and } \\
\text { activities were an integral part of a larger campaign }\end{array}$ \\
\hline
\end{tabular}

A: authorities; B: businesses; R: researchers; P: practitioners; E: educational institutions; O: non-governmental organizations; CP: campaign partnerships; DP: development partnerships; PDP: product development partnerships; PPP: product promotional partnerships.

proaches are not always acceptable to state authorities.

Authorities took part in almost all of the partnerships in the study and the concrete messages of the partnerships are thus to an overwhelming extent approved or sanctioned by a public body. The evaluation showed that businesses and NGOs assessed the authoritative nature of the partnerships to be an important asset.
Researchers are another important public partner and play an important role, especially in knowledge creating partnerships. Authoritative research-based knowledge is vital in both campaigns and development partnerships, and researchers have the opportunity to use partnerships as research cases and to become involved in partnership projects together with practitioners. It is thus natural that many partnership projects can include both an action 
Table 2. Typology of different activities of partnerships: each partnership can involve more than one activity (the typology is based on the observations in the study)

\begin{tabular}{|c|c|c|c|c|}
\hline Type & Quality & $\begin{array}{l}\text { Important } \\
\text { actors }\end{array}$ & Possible outcome & Activities \\
\hline $\mathrm{CP}$ & Campaign partnerships & $\begin{array}{l}\text { Authorities, } \\
\text { organizations }\end{array}$ & Healthier eating habits through information & $\begin{array}{l}\text { Partnerships containing campaign activities for promoting } \\
\text { healthy eating habits where the message is already clear }\end{array}$ \\
\hline DP & $\begin{array}{l}\text { Development } \\
\text { partnerships }\end{array}$ & $\begin{array}{l}\text { Researchers, } \\
\text { practitioners }\end{array}$ & New knowledge, hypotheses, models & $\begin{array}{l}\text { Partnerships that aim to create new knowledge necessary } \\
\text { for promoting healthy eating habits }\end{array}$ \\
\hline PDP & $\begin{array}{l}\text { Product development } \\
\text { partnerships }\end{array}$ & Food industry & New healthy products or product ranges & $\begin{array}{l}\text { Partnerships with the objective of developing new healthy } \\
\text { products }\end{array}$ \\
\hline PPP & $\begin{array}{l}\text { Product promotional } \\
\text { partnerships }\end{array}$ & Retail chains, catering & Increased sale of specific healthy foods & $\begin{array}{l}\text { Partnerships that aim to promote the use of specific healthy } \\
\text { foods }\end{array}$ \\
\hline TP & $\begin{array}{l}\text { Transcendental } \\
\text { partnerships }\end{array}$ & $\begin{array}{l}\text { Food industry, retail } \\
\text { chains, catering }\end{array}$ & $\begin{array}{l}\text { Healthier eating habits through long-term active } \\
\text { participation and responsibility of industry }\end{array}$ & $\begin{array}{l}\text { Partnerships that aim to create a corporate nutritional } \\
\text { responsibility of a food company }\end{array}$ \\
\hline
\end{tabular}

CP: campaign partnerships; DP: development partnerships; PDP: product development partnerships; PPP: product promotional partnerships; TP: transcendental partnerships.

research element and a development or campaign element. Researchers have also given strength to many partnerships because the documentation of the effectiveness is a motivating factor for both the partners and the target group that is to be influenced.

Businesses are also an important actor. The strength of businesses in partnerships lies in the fact that healthier eating habits to a large extent are a question of availability of healthy foods. Here the food industry plays an important role. Even though much can be achieved through knowledge-generating and campaign-related activities, healthy eating habits cannot be radically advanced without the active participation of the food industry, catering operators and retail chains in the partnerships. This role of business was assessed to be important in many cases. Product development, outlet strategies and promotional activities are involved to secure the availability of healthy foods. In addition, the timing of these in relation to related campaign activities is important.

\section{Resources}

Resources are essential for partnerships. The evaluation process showed that a large number of resources has been brought into play in the partnerships. These include:

- financial resources

- human resources

- creative resources

- product development resources

- research knowledge
- research knowledge translated to communicable messages

- easy access to target groups

- easy access to supply channels.

Figure 1 illustrates the promising feature of partnerships: that, through an iterative process of exchange of ideas and knowledge brought about by a lasting relationship between partners, they can as an outcome obtain better results than those they could have obtained by working alone.

\section{Discussion}

The individual is ultimately responsible for dietary choices, but creating the right framework for the healthy choice is of societal concern and it is in this context that partnerships seem to be a very promising way forward. As the evaluation shows, the existing partnerships have had considerable success in promoting healthy eating. To develop partnerships further it is therefore relevant to discuss the strengths and weaknesses that were identified in the evaluation.

From the authorities' point of view, one of the most interesting perspectives offered by partnerships is that they make it possible to promote healthy eating more effectively if other actors gradually take increasing responsibility for tasks previously handled primarily by the state alone.

In the case of nutrition, health risks are linked to the amounts of foodstuffs and composition of the diet, and therefore efforts must be directed towards promoting, inspiring and motivating people to adopt healthy eating habits. Availability, quality 


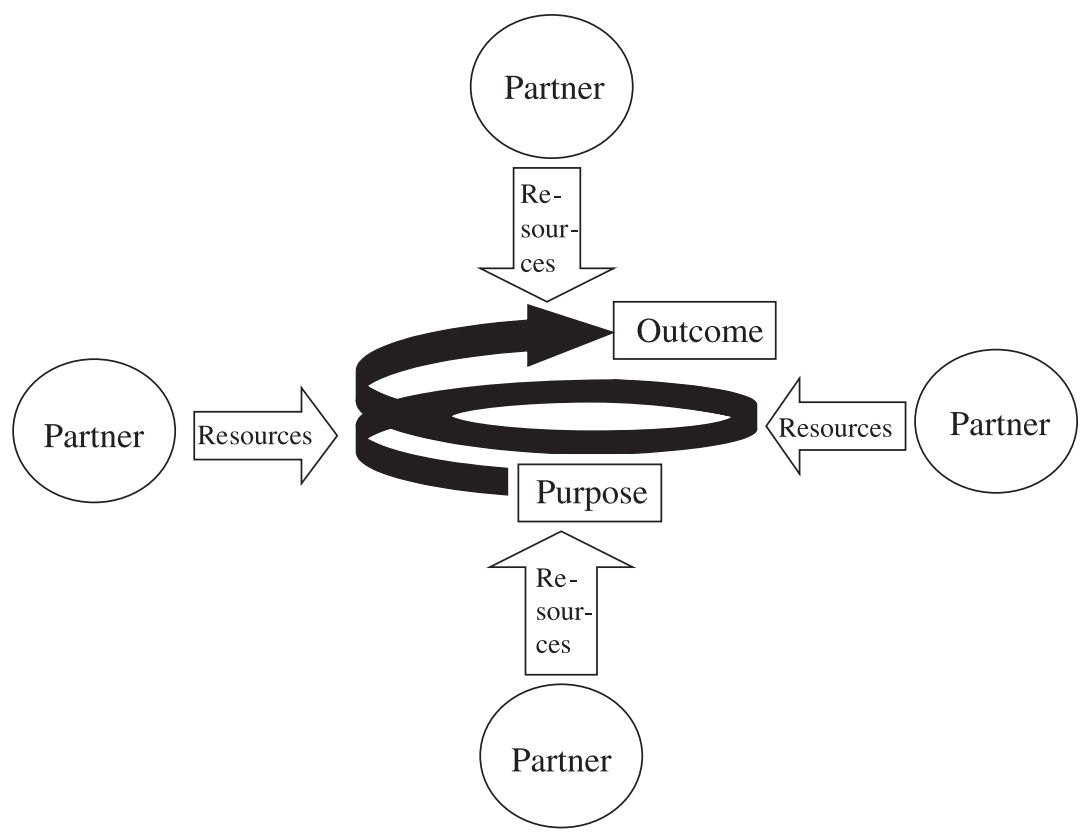

Fig. 1. Various partners in a partnership contribute a number of individual resources in relation to a formulated purpose, well-defined activities and a desired outcome.

and price are vital in this respect. Campaign, information and educational activities can be implemented through partnerships between producers and public authorities, but success also depends on the adequate availability of the foods in question.

Therefore, there is an increasing agreement that businesses are vital partners in healthy eating partnerships. As when companies started to take action in the environmental field in the 1980s, a similar expectation is now beginning to evolve regarding the companies' responsibility for the health and nutritional effects that the consumption of their products have on the individual and in a society.

As the study indicates, it is relatively unproblematic to enter "obvious" partnerships, for example when producers and suppliers in partnership with the authorities promote specific foods for nutritional reasons. It is the area of fruit and vegetables (6-a-day) from which some of the most valuable experiences with partnerships can be collected.

In comparison, it is a lot more demanding - but nevertheless promising - to establish partnerships in which food companies are developing their CNR. [The term CNR is suggested with reference to the discussion about corporate social responsibility, in Morsing and Thyssen (12).] In this context CNR implies making nutritional issues a corporate man- agement issue. Such an approach might include activities such as:

- development of healthier versions of unhealthy foods

- development and branding of healthy product ranges

- development of new healthy foods

- development of nutrition educational material

- improving nutritional labelling of products

- involvement in dialogue on nutrition with experts and consumers

- promoting nutrition research

- adoption of a nutritional policy and action plans

- including nutrition issues in corporate image

- developing a credible code for marketing of foods.

The first attempts at such transcendental strategies were seen where Danish food retailers tried to make it easier to make healthy choices through labelling schemes, and catering operators' attempts to arrange whole ranges of meals that promote healthy choice. There is, however, still a need for more examples of far-sighted "early movers" who enter such transcendental partnerships with the public sector, with the aim of taking nutritional responsibility. 
The extent to which companies enter partnerships owing to expectations of making a profit, or to a more general corporate governance approach, is not known, and more knowledge and further research on this issue are needed. There is a risk that the involvement of authorities can serve as an approval of initiatives taken by the company other than those being covered by the partnership's target. Unintentionally, activities not in accordance with nutrition policy goals can thus appear to be authorized. In addition, there is a risk that only well-performing companies are offered partnerships, eventually leading to even better performance, while less wellperforming companies are left behind. State authorities also need to consider issues of equality of treatment. This applies, for example, to the question of whether state authorities can be permitted to enter partnerships with selected businesses and actors while excluding others from these partnerships.

Besides the public and the companies, the NGOs have important roles to play in partnerships of healthy eating, and this is in accordance with the experiences of partnerships in other fields of society. NGOs are important since their credibility is often high, and because dissemination through NGOs is very efficient. Together with public partners they have access to a variety of resources, which make synergy effects very likely to occur. As pointed out in the evaluation, one strength of partnerships is that they have a greater impact on their target groups than the individual actors would have working alone. The possibility of making the "whole greater than the sum of its parts" is the central idea in partnerships and in accordance with Håkansson's (10) theoretical considerations about resources.

In development partnerships this means that it is easier to involve local stakeholders or practitioners at schools or workplaces, etc., which is essential to the success of the project and sustainability of the project's results. In the case of campaign partnerships, the partnership is in a much stronger position when addressing the target group because it can issue joint statements. Partnership projects including state participation are gaining an authoritative role, which is a clear asset to both businesses and NGOs, although some organizations can experience problems owing to the risk of adhering too closely to the authorities' point of view.

However, experiences in campaign partnerships show that it can be a problem to work in the very changeable world of information. It requires con- siderable media know-how and agreement upon when the individual partners will be profiled to the public. Another drawback that must be taken into consideration is that partnerships are time consuming and demand high staffing levels. It is difficult to speed up the process, since obtaining familiarity with the other partners' way of thinking and working takes time.

The likely synergy effects of partnerships are illustrated in Fig. 1. By cooperation and by devoting time and resources to the partnership according to an agreed purpose, the partners enter a relationship in which knowledge is continuously increasing and in which the end result is better than the one they could have obtained as individuals.

This study has pointed out a number of strengths and weaknesses of partnerships. To promote the establishing of future partnerships, a number of conditions and requirements that must be met to be able to develop and maintain successful partnerships has been drawn up on the basis of the evaluation.

- It is important that time and energy is allocated to agreeing the ground rules for internal cooperation in the partnership, including communication with the outside world. Many recognized project work methods can be put to use here.

- The objective of the partnership must be concrete if it is to be attractive to practitioners. There are, however, interesting possibilities in researchers becoming involved together with practitioners in projects that contain both a research element and a development or campaign element.

- The partners' different skills must be used if the hypothesis that partnerships are in a position to create added value is to be confirmed. By using and sharing knowledge and through valuing and exploiting partners' differences, genuine synergy can be created even though partners enter partnerships with different resources. It is a condition that partners can cooperate on an equal footing.

- Social relationships are vital in the creation of partnerships. This means that actors who want to enter partnerships must be ready to establish and maintain a solid professional network.

- Besides the public, NGOs and industries are important actors in partnerships. It is important to be aware that not all of these are strong in terms of resources. These potential partners can, however, appear to be strong in terms of creativity and impact on the target group. 


\section{Acknowledgements}

Thanks to Michael Søgård Jørgensen and Astrid Dahl at Department of Manufacturing Engineering and Management at the Danish Technical University for useful comments on the manuscript.

\section{References}

1. World Health Organization. Obesity: preventing and managing the global epidemic. Report of a WHO consultation on obesity. Technical Report Series, no. 840. Geneva: WHO; 1997.

2. Richelsen B, Astrup A, Hansen GL, Hansen HS, Heitmann B, Holm L, et al. The epidemic of obesity in Denmark - outline of a prevention strategy. Copenhagen: Danish Nutrition Council; 2003.

3. Førde B, ed. Building partnerships: lessons from Kenya and Zambia. Copenhagen: Mellemfolkeligt Samvirke; 2000.

4. Greve C. Governance by contact: creating publicprivate partnerships in Denmark. Copenhagen: Institut for Statskundskab, Copenhagen University; 1999.

5. Osborne SP. Public private partnerships - theory and practice in international perspective. Advances in management and business studies, No. 19. London: Routledge; 2000.

6. Davies JK. Partnership working in health promotion: the potential role of social capital in health development. In: Balloch S, Taylor M. Partnership working. Bristol: Policy Press; 2001. pp. 181-200.
7. Søndergård B, Hansen OE, Kerndrup S. Renere produktion i et innovationsperspektiv (Cleaner production in an innovation perspective). In: Holm J, Kjærgård B, Pedersen K, eds. Miljøregulering - tværfaglige studier. Roskilde: University Publishing; 1997. (In Danish.)

8. Geunes J, Panos P, Romeijn HE. Supply chain management - models, applications, and research directions. Applied Optimization, No. 62. Dordrecht: Kluwer Academic; 2002.

9. Tarrant V. Partnership in the food chain - the role of support players. Food Sci Technol Today 1996; 10: 35-8.

10. Håkansson H, Snehota I, eds. Developing relationships in business networks. London: Routledge; 1995.

11. Anon. Collection of posters for conference held by Danish Ministry for Food, Agriculture and Fisheries on Partnerships for healthy foods, 2 October 2003, Copenhagen. Available from: URL: http://www.fvm.dk (cited November 2003).

12. Morsing $M$, Thyssen $C$, eds. Corporate values and responsibility - the case of Denmark. Frederiksberg: Samfundslitteratur; 2003.

Bent Egberg Mikkelsen

Department of Nutrition

Danish Institute for Food and Veterinary Research

Mørkhøj Bygade

19 DK-2860 Søborg

Denmark

Fax: +45 3395 ।। 19

E-mail: bem@dfvf.dk 